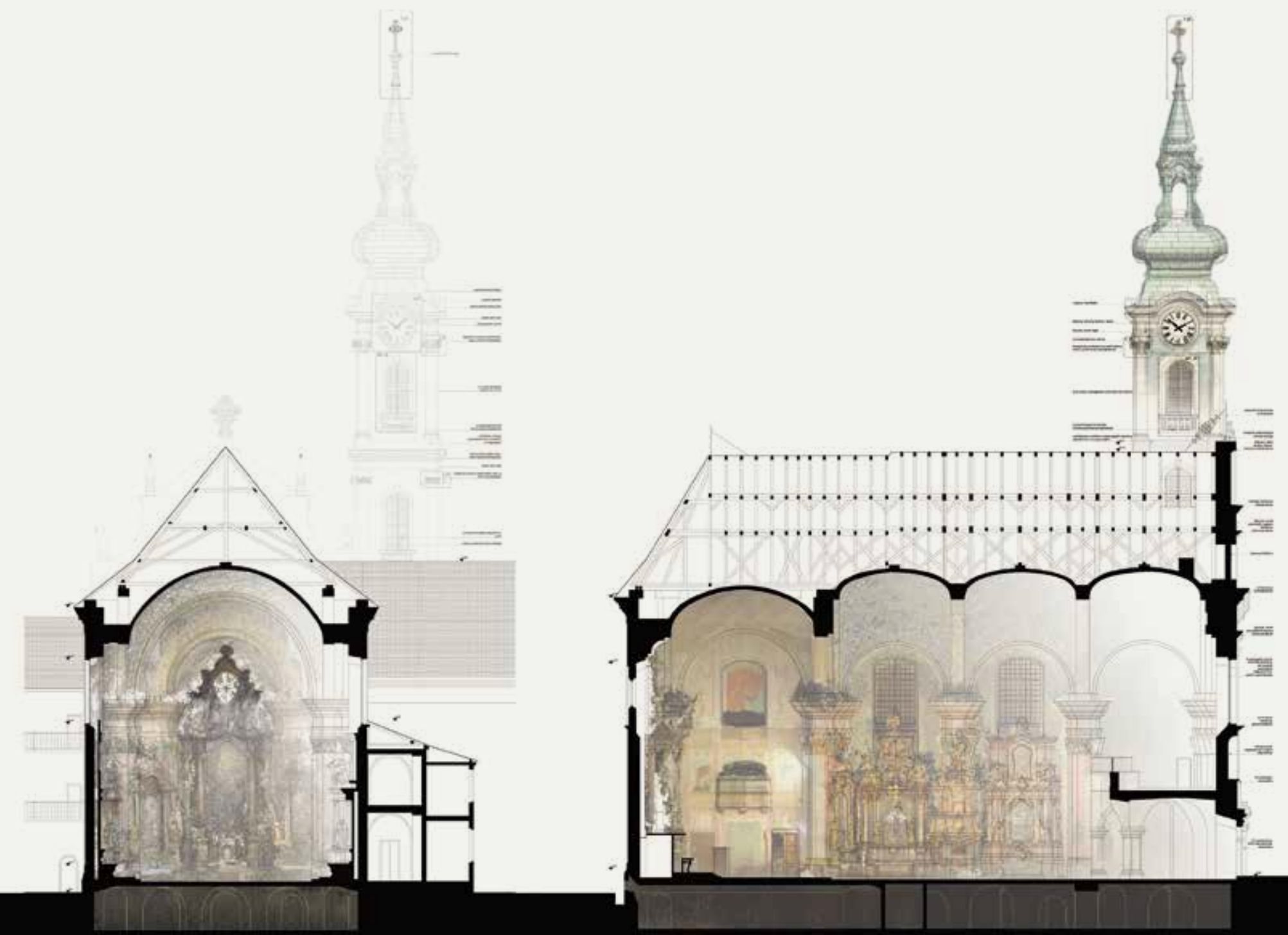

\title{
KIRAGYOGVA
}

\section{A BUDAI SZENT FERENC SEBEI TEMPLOM FELÚJÍTÁSA}

_Egyszerúségében is megkapó építészeti beavatkozás eredménye gazdagítja immár a budai Fő utcát: felújították a Szent Ferenc sebei római katolikus templom homlokzatait. A Z. Halmágyi Judit és Tóth Tamás vezető tervezők által jegyzett, az egykori ispotály és rendház között szerényen, korábban alig észrevehetően meghúzódó, újjászületett épület a szerepéhez és történetéhez méltón, erős kisugárzásával gyakorol hatást környezetére.

_A környezet - a ZHJ építészcsapatától jól ismert tervezésmetodika szerint a lehető legtágabb értelemben veendő: a fizikai Világörökséghez tartozó Duna- 05 parti és vári panorámától a szellemi és spirituális értelemben vett környezetig. 


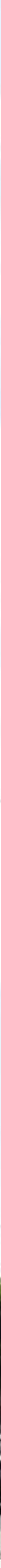

03 A kolostoregyüttes a felújított templomhomlokzattal

04 Déli homlokzat a megújult toronnyal

05 A kolostoregyüttes a budai part városképében

változásnak, a barokk formájú toronysisak átépítésének hatására viszont még erősebb vizuális kapcsolatba került a környezetét jelentő barokk épületegyüttes leghangsúlyosabb elemével, a Szent Anna-templommal (melynek fontosságát emeli, hogy a Fő utcából csak szűk rálátás nyílik a főhomlokzatra). A háborúban erősen sérült homlokzatokat a hetvenes években rekonstruálták, 2000-ben a Fő utcai homlokzaton vakolatjavítás, festés és kőrestaurátori munkák készültek, de a torony vakolatjavítása elmaradt, így ez nem alkotott kompozíciós egységet a homlokzat többi részével. A következő években a vakolatjavítás folytatódott az északi és keleti oldalon, de a déli oldalon nem. A műemléki felújítás fontos célkitűzése volt az eredeti állapot kompozíciós egységének visszaállítása, egységes színezése (az eredeti árnyalat már a falkutatásokkal sem volt fellelhető). A szennyezett és sérült vakolat megújítása mellett a külső munkák része volt még a toronysisak javítása, homlokzati tagozatok rekonstrukciója, a kő-, fém- és 12 faelemek restaurálása is, melyek között kiemelt értéket képviselt a főhomlokzat kapukeretezésének plasztikus díszítéssel ellátott felépítménye, és a templomon található három kereszt felújítása. A homlokzati részletek felújításánál irányelvnek számított a patinás megjelenés lehető legteljesebb, valamint a megtartható épületrészek (például az eredeti barokk ablak) megőrzése. A teljes homlokzatrekonstrukcióhoz azonban szükség volt az építészek rendkívül korszerű technikai felkészültségére (például pontfelhő alapú fotogrammetriai felmérési technológia alkalmazása), 02 és nagyon alapos levéltári kutatómunkára (eredeti tervrajzok, fotódokumentációk) is, hogy az idők során megsemmisült részleteket is pótolni tudják. Így kerülhettek fel ismét az épületre az idők során megsemmisült épületelemek rekonstrukciói, mint a timpanon sarkain elhelyezkedő obeliszkek, a főpárkány északi oldalán található püspökszobor, az oromkeresztet díszítő puttók, vagy a toronyóra. _ A belső helyreállítás bő egy évtizeden keresztül készült közvetlenül a rendszerváltás előtt. A templomtér restaurált barokk szentélyfestménye, dúsan faragott padsorai, I9. 

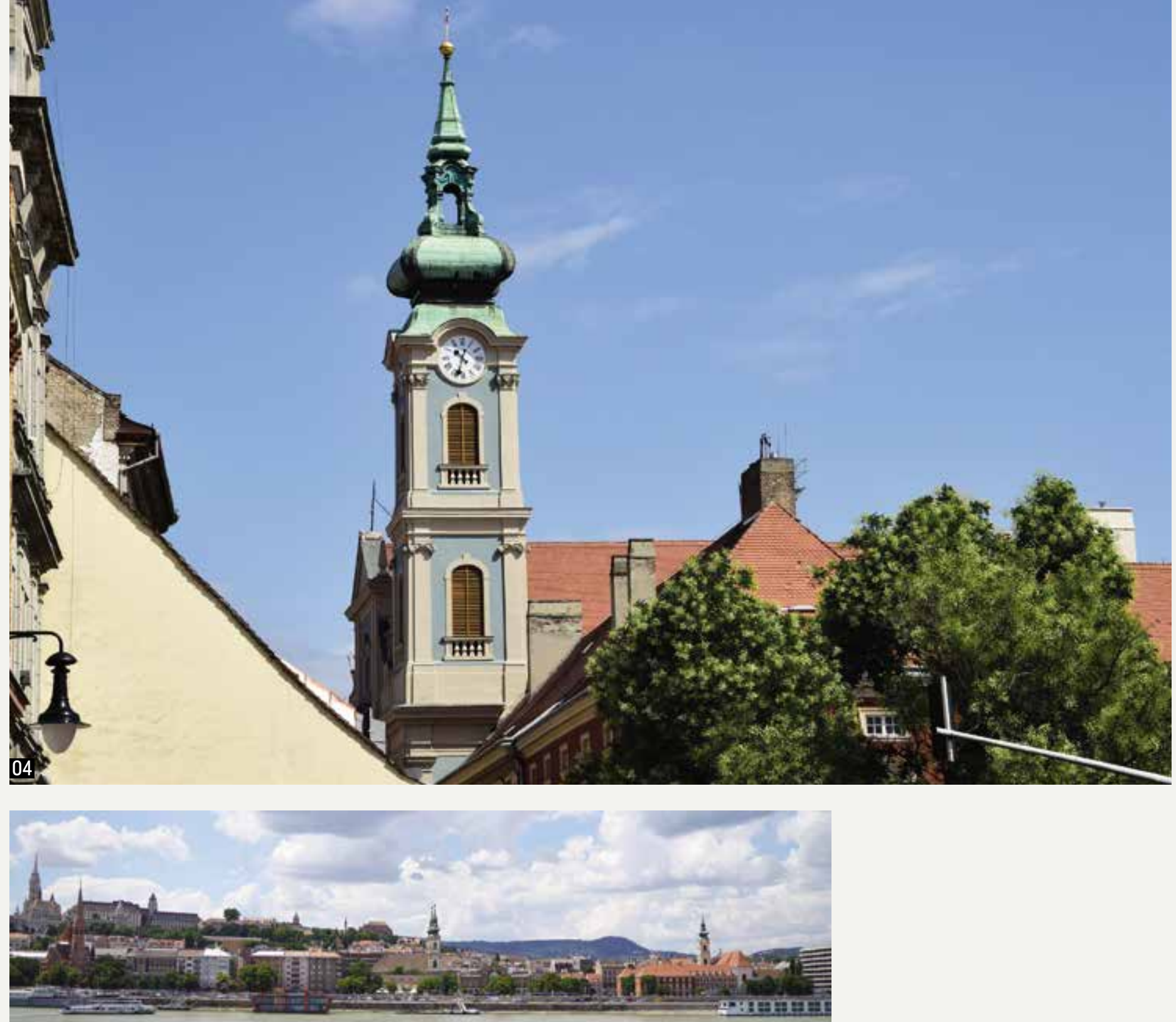

05

század végi, de ritkaságszámba menő orgonája a I8. században, a török hódoltság megszünése után meginduló és felvirágzó rendi építészet jó színvonalú emlékei közé sorolják az épületet. A templombelső részleteinek aprólékos megmunkálása és egységes, jó minőségben megtartott állapota az itt jelen lévő Erzsébet nővérek gondosságának is bizonyítékai. A 2020 tavaszára elkészített külső homlokzatrekonstrukció méltó folytatásává vált ennek a rendkívül alapos belső felújításnak.

_ A külső és belső tér egy ponton minőségben, fizikailag és szellemileg is kiemelten összeér: az oltár fölötti Szentlélek-ablak - a külső és belső világ ékeként - új formában építi tovább a teret. A templomhajó ólomkristály csillárjai által ihletett, a barokk művészi extázisát kortárs formában újraíró „kaleidoszkóp-nyílás” üvegrétegei egyszerre gyüjtik össze és szórják szét a fényt kelet felől és felé - a nyugati, sugaras szerkesztésű rózsaablakok analógiájára, a Szent Erzsébet-rózsák mintájára - a Bensőt kiragyogva.
IRODALOM / REFERENCES

[1] Pokorny, Emánuel Dr: A Szent Erzsébet-szerzet, tekintettel budapesti kolostorára, templomára és női kórházára, Szerzői kiadás, Budapest, A Szent István Társulat Bizománya, 1935, pp.: 5-20.

[2] Bor, Ferenc - Tóth, Timea: Budapest I Fő utca 41-43, Bem József rakpart 29, Szent Ferenc Sebei római katolikus templom, Műemléki tudományos dokumentáció és értékleltár, Hild-Ybl Építéstörténeti és Műemléki Kft, Budapest 2018, pp 35-41. 


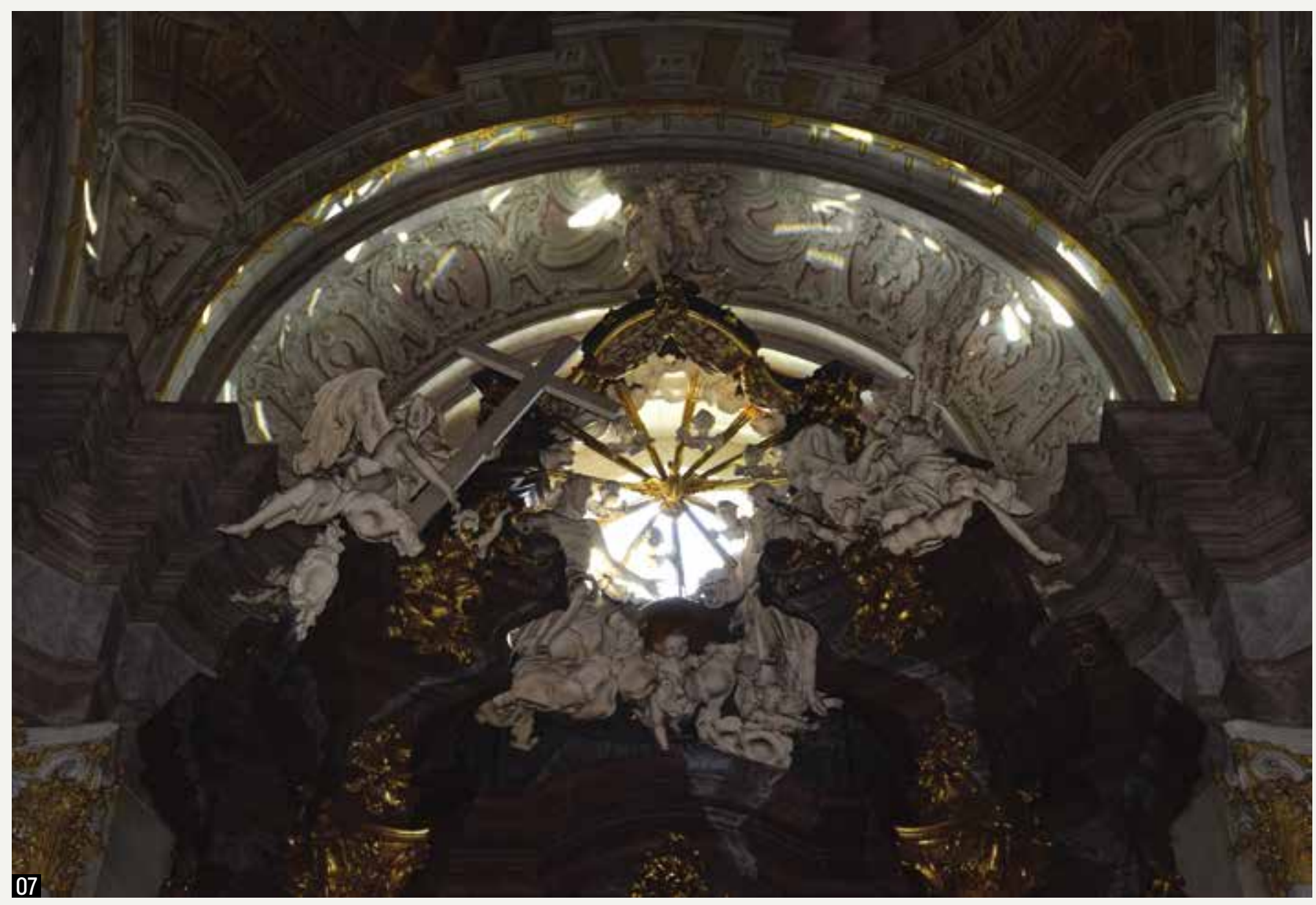

személyét ismerjük: Hans Jakab (?-I747) kőmíves pallér vezetése alatt építették fel a templomot és a tornyot is. [3]

_ A templom belső berendezése és díszítése a rend saját műhelyében készült a következő évtizedben. Ferences fráterek keze munkáját dicséri, akik közül többük neve is fennmaradt, úgy mint a vasmunkákat készítő Cikoria Miklósé, a festőés szobrászmunkákban részt vevő Kranovetter Józsefé, Huber Bonifácé, Pőtzl Dánielé, Sigmund Cipriáné, Ritzner Thimóté, Videmon Izidoré. _ A főoltár I756-ra készült el Pavich Imre teológiatanár gondozása és felügyelete alatt, valószínűleg szintén a rendi mühely alkotásaként.
A szentély kifestése még a főoltár felszentelése előtt elkészült, mennyezetképének közepén az assisi Santa Maria degli angeli templom ábrázolásával. 1743 pünkösdjén szólalt meg először a 27 változatú, kétmanuálos, mechanikus csúszkarendszerű orgona, amelyet feltehetőleg Videmon testvér készített társaival több mint egy évig tartó munkával. [4] I749 és I752 között készült el Bernucca Péter adományából a remekbeszabott szószék, amelynek készítője Kranovetter József, a rendi műhely festő és szobrász testvére volt. [5] Szintén a kapisztránus mühely munkái lehetnek a templom gazdagon faragott padsorai, ezek I756-ra lettek készen. [6]
_ A templomot I757. szeptember I8-án, a Szent Ferenc stigmatizációja ünnepét követő napon szentelte fel a stigmatizált Szent Ferenc tiszteletére Zbisko József Károly tinnini püspök.

A templom és a kolostor ezután alig három évtizedig volt a ferencesek tulajdonában és használatában. II. József I784. október I5-én, a rend feloszlatását követően szemlét tartott a kolostorban, katonai kórháznak alkalmas épületet keresve. I785. szeptember 25-én kelt rendeletével a vízivárosi kolostort és templomot a Szent Erzsébet szerzet*** bécsi kolostora I8 apácájának adta át az uralkodó, a kapisztránus ferenceseknek pedig a feloszlatott 

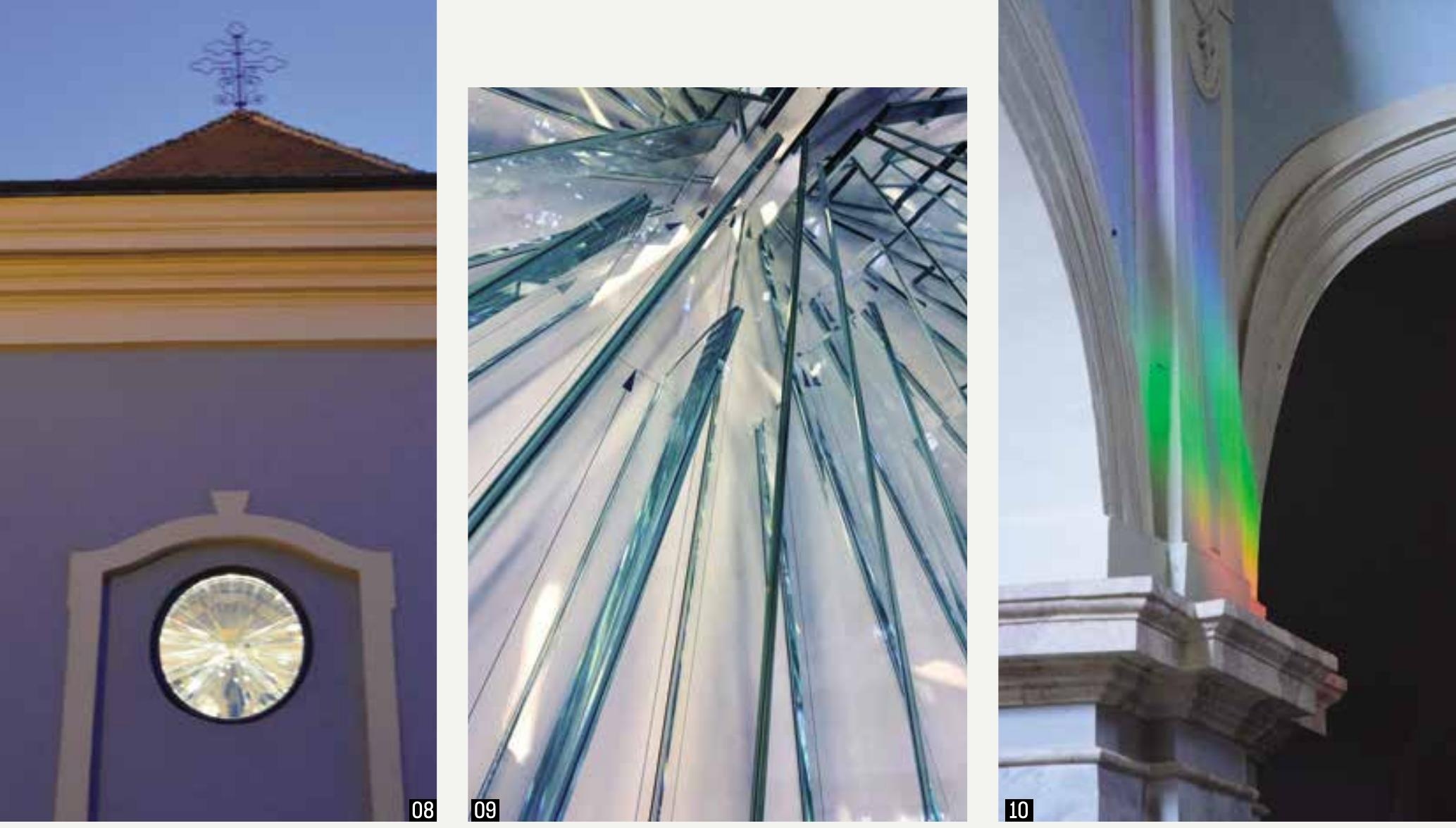

augusztiniánus rend Ország úti kolostorába kellett átköltöznie. Az erzsébet apácák idején a templom architektúrájában gyakorlatilag egyetlen, azonban annál jelentősebb változás történt, amellyel a templom elnyerte végleges formáját. I89I-ben a torony gúlasisakját a főváros Eberling István fővárosi osztálymérnök terve szerint lecseréltette a Szent Annaplébániatemplom toronysisakjaihoz hasonló, párnatagos, lanternás bronzborítású ácsszerkezetre.

\section{TÓTH TIMEA}

*A ferences rend, más néven ferencesek, régebbi nevén franciskánusok: római katolikus szerzetesrend, melyet Assisi Szent Ferenc (1182. január 12. - 1226. október 4.) alapított 1209-ben. Ferences testvérek még Assisi Szent Ferenc életében, már 12251226 körül érkeztek Magyarországra. Az első rendtartomány, melyet Esztergomi vagy Magyarországi Provinciának neveztek, 1232ben vagy 1233-ban vált önállóvá. IV. Béla király segitői voltak a tatárjárás utáni újjáépitésben. A török hódoltság után a testvérek és a házak száma is gyarapodásnak indult. Ekkor
Magyarország északnyugati részén a Mariánus Rendtartományból a Szent László Királyról Nevezett (Ladiszlaita) Provinciát, Erdélyben a Szalvatoriánus Tartomány házaiból az erdélyi Szent István Király (Stefanita) Provinciát, majd az ország szivében, Budáig terjedő részen 1757-ben a Bosnyák-Bányavidéki Provincia hazánkba érkező testvéreinek magyarországi házaiból a Kapisztrán Szent Jánosról Nevezett (Kapisztránus) Provinciát állitották fel.

** Pokorny Emánuel „Tojgun pasától, Buda egykori kormányzójától épült mecset"-ként jelöli meg az épületet. Ez tévedés, mivel a későbbi kutatások Tojgun pasa mecsetjének helyét a mai Fô utca 32.-ben azonosították. Ezt a dzsámit a kapucinusok kapták meg, helyén a kapucinus templom épült fel. [1] Horler Miklós Maktúl Musztafa pasa minarés mecsetjeként jelöli meg az itt álló dzsámit. [3]

${ }^{* * *}$ A budai Erzsébet apácák az aacheni Erzsébet apácák (elizabetánusok) egy csoportja: egyházmegyei jogú betegápoló szerzetesi kongregáció. 1626. V. 5-én Aachenben alapította Apollonia Radermecher. Eleinte jezsuita, majd 1624-tól obszerváns ferences lelkivezetés alatt álltak. 1650-ben Grazban, 1709-ben Bécsben telepedtek meg. Bécsből jöttek nővérek 1738-ban Pozsonyba, 1785-ben Budára. [7]
IRODALOM / REFERENCES

[1] Gerő, Győző: „A Buda-vízivárosi Tojgun pasa dzsámi és a Tojğun pasa Mahalle", Budapest Régiségei XXXVII, 2003, pp 197-208.

[2] Pokorny, Emánuel: A Szent Erzsébetszerzet, tekintettel budapesti kolostorára, templomára és női kórházára, Budapest 1935, p 24.

[3] Horler, Miklós, et al: Budapest múemlékei 1. (Magyarország műemléki topográfiája IV kötet), Budapest 1955, p 652.

[4] Pokorny 1935, p 91.

[5] Nagy, Lajos: Budapest története 1686-1790, Budapest története III - A török kiüzetésétől a márciusi forradalomig, Budapest 1975, p 238.

[6] Horler 1955, p 654.

[7] Aacheni Erzsébet apácák, Katolikus lexikon, hozzáférhető: <http://lexikon.katolikus. hu/A/Aacheni\%20Erzs\%C3\%A9bet\%20 ap\%С3\%A1c\%C3\%A1k.html> [utolsó belépés: 2020-08-25] 

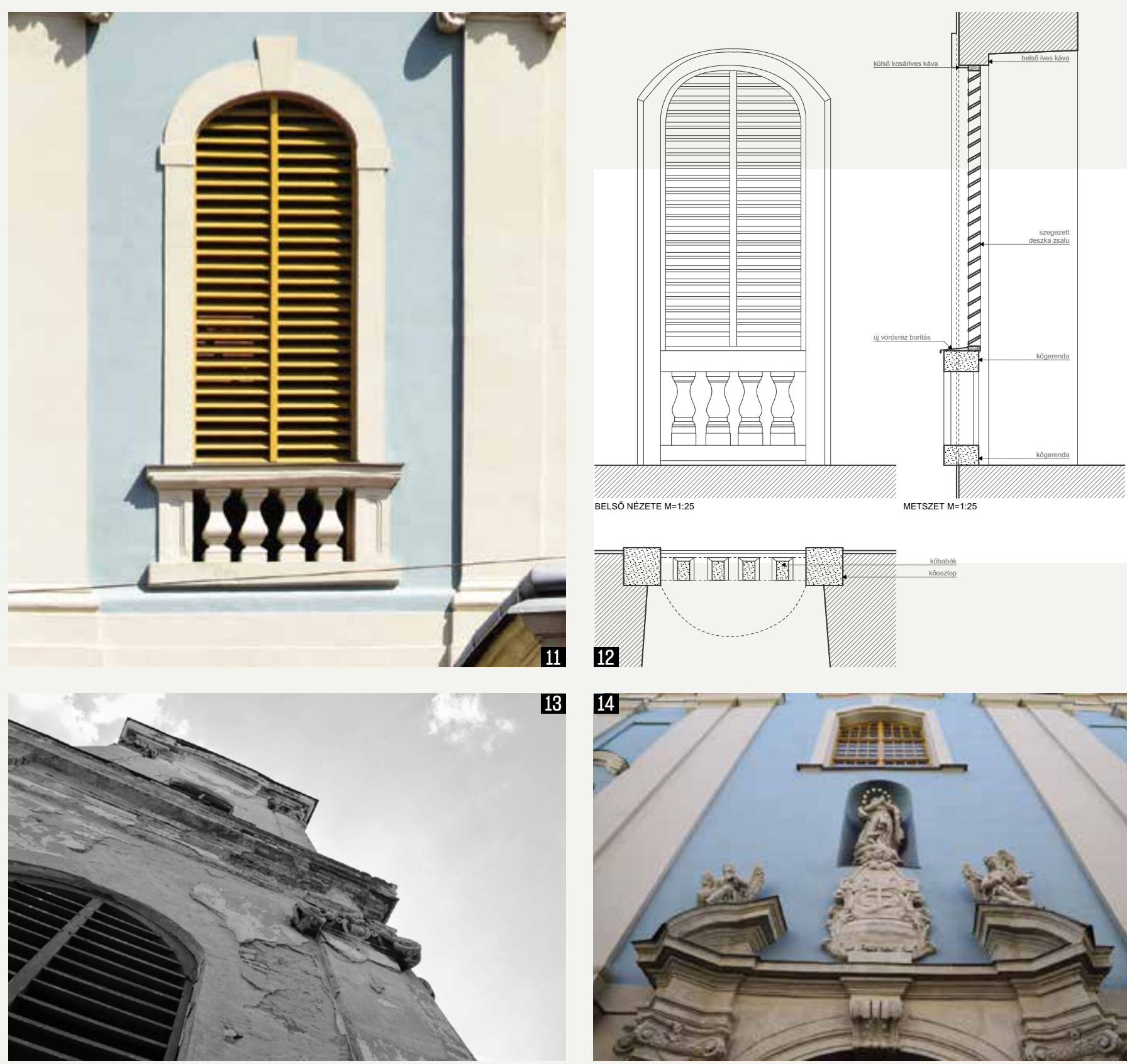

13

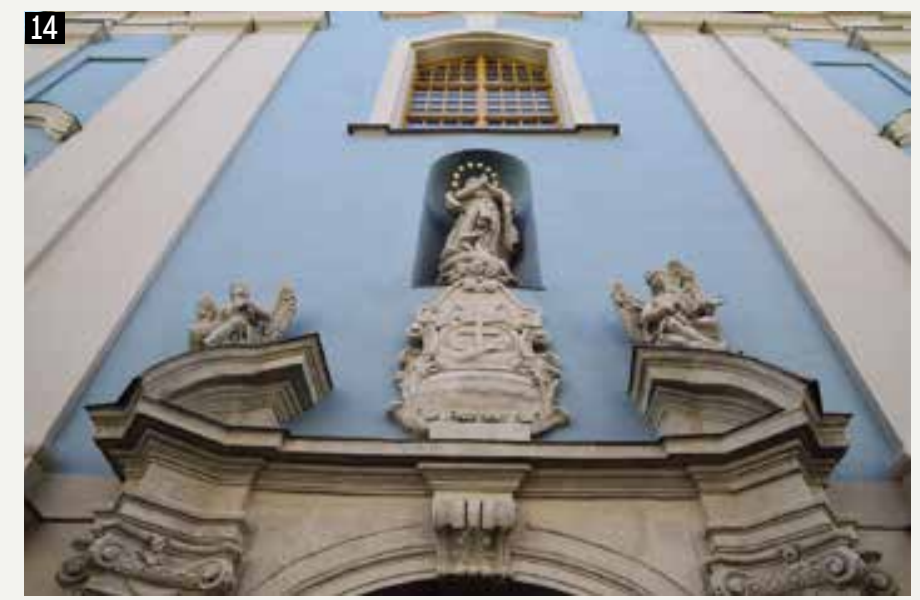

08 A Szentlélek-ablak kívülről

09 Közeli kép munkaközi állapotban

10 Szivárványszín fényfolt a templombelsőben

11 A toronyablak felújítva

12 Az ablak tervei

13 Felújítás előtti állapot

14 A főbejárat feletti szoborcsoport is megújult

ÉPÍTTÉPÍTÉSZ: Z. Halmágyi Judit, Tóth Tamás | PROJEKTÉPÍTÉSZ: Miklós Bernadett | MEGBÍZÓ: Esztergom-Budapesti Főegyházmegye | ÉPÍTÉSZ MUNKATÁRSAK: Tóth Ágnes, Somkutas Bianka, Gacsályi Kinga, Tódor György Emánuel | 3D PONTFELHőS FELMÉRÉS: Miklós Bernadett | MÜEMLÉKVÉDELMI TERVDOKUMENTÁCIÓ: Bor Ferenc, Tóth Timea, Hild-Ybl Alapítvány | BELSŐ ÉRTÉKLELTÁR: Molnár Ádám I SZENTÉLY-ABLAK: Bokor Gyöngyi, Csizmadia Zsolt iparművészek | KÉPVISELŐ, LEBONYOLÍTó: Németh Tamás építész, Kima Stúdió | KIVITELEZÉS: Molnár \& Molnár Kft. | PROJEKTMENEDZSMENT: EKRON Consulting Kft., Vaits Zoltán, Land Marking Kft. | MŰSZAKI ELLENŐR: Bonifert Zoltán | GENERÁLTERVEZŐ: Z. Halmágyi Judit, ZHJ Architects | HOMLOKZATREKONSTRUKCIÓS TANÁCSADÓ: Pintér László, Saint Gobain Hungary | FARESTAURÁTOR: Bodnár Gyula | FÉMRESTAURÁTOR: Páhi Attila | KŐRESTAURÁTOR: Osgyányi Vilmos | FALRESTAURÁTOR, FALKUTATÁS: Fazekas Gyöngyi | VILLÁMVÉDELEM: Szabó Pál Zoltán | ÁCS: Hum Antal | TORONYÓRA: Kapui Gyula | FOTÓ: Miklós Bernadett, Molnár Ádám, Z. Halmágyi Judit 


\title{
ABSTRACTS
}

\author{
ARNÓTH, Ádám: INTERNAL WEALTH \\ Citation: Metszet, Vol 11, No 5 (2020), pp 18-25, DOI: 10.33268/Met.2020.5.1
}

SYNAGOGUE RESTORATION, BUDAPEST, HUNGARY | Restoration Architect: Tamás KŐNIG DLA and Péter WAGNER DLA

Originally designed in the Moorish Revival style by Otto Wagner in 1873, this synagogue served as a place of worship for the more conservative members of Budapest's Jewish community. WWII damage left the building

\author{
in a ruinous state, although repairs to the \\ structure did occur, restoration in earnest did \\ not start until 2007. The subsequent works \\ have restored this place of worship to its \\ former splendor and function. Attention payed
}

to the original design, the Torah Ark and unusual use of Moorish decorative elements have helped demonstrate why this building is one of Budapest's significant historic monuments.

\section{LÉVAI, Tamás: TIME TRAVEL}

Citation: Metszet, Vol 11, No 5 (2020), pp 26-31, DOI: 10.33268/Met.2020.5.2

PJ VILLA, KOLOZSVÁR (CLUJ-NAPOCA), ROMANIA | Architect: Miklós PÉTERFFY

Originally designed in 1937, an amazingly exciting period for architecture anywhere, this family home has recently been modernized.

Or has it been restored to its intended form, with updated technology, use of space and materials. Division of spaces has been achieved by feats of geometry on a grand scale, with curved walls and high ceilings developing a perfectionist feeling drawing inspiration from the 1930s desire for luxury. A possible destination for architectural tourism for those departing from Budapest.

\section{CSANÁDY, Pál: MILITARY LEGACY}

Citation: Metszet, Vol 11, No 5 (2020), pp 32-37, DOI: 10.33268/Met.2020.5.3

LMCC ARTS CENTER, GOVERNORS ISLAND, NEW YORK, USA | Restoration Architect: Jay L. BERMAN

A former military base has seen a nineteenthcentury munitions warehouse converted into a venue for the arts by the Lower Manhattan Cultural Council with the intention of creating spaces for temporary exhibitions, studio spaces and public events. As one of the few green park areas of New York this offers a location not only for the arts but also for leisure time activities. The key to this project's success being the fact that a minimum level of work was required due to the architectural strength of the existing building.

\section{WETTSTEIN, Domonkos: SPACE-TIME ILLUSION}

Citation: Metszet, Vol 11, No 5 (2020), pp 38-43, DOI: 10.33268/Met.2020.5.4

STADT CASINO, BASEL, SWITZERLAND | Architects: HERZOG and DE MEURON

The designers of this project have taken an approach similar to that of an Eszterházy novel: travelling through a multifaceted

history of spaces from point of view to point of view. This might be an act of fantasy or irony resulting in a restoration of neobaroque elements, insertion of contemporary interventions, resulting in maintaining the original acoustic quality of the concert hall and improved non-performance circulation areas: foyer, stairwells and corridors which now create a new sequential flow throughout the building complex.

\section{WARE-NAGY, Orsolya: REALISTIC, WALK-IN MODEL, OR THE NEW OLD}

Citation: Metszet, Vol 11, No 5 (2020), pp 44-49, DOI: 10.33268/Met.2020.5.5

RESTORATION OF THE HORSE RIDING-HALL, BUDAPEST, HUNGARY | Restoration Architects: Ferenc POTZNER

A key element of the National Hauszmann project to restore or rebuild monumental buildings in Budapest's Castle District includes this Riding-Hall damaged in WWII and finolly demolishedin the 7050 s when a building is totally demolished rebuilding to original plans will not occur due to changes in materials, construction methods or statutory requirements. The question arising or a full-scale architectural model" erected in an attempt to satisfy grandiose plans or a false sense of history?

\section{CSONTOS, Györgyi - TÓTH, Timea: ENLIGHTENMENT}

Citation: Metszet, Vol 11, No 5 (2020), pp 50-57, DOI: 10.33268/Met.2020.5.6

CHURCH OF THE STIGMATIZATION OF SAINT FRANCIS, BUDAPEST, HUNGARY | Restoration Architects: Judit Z. HALMÁGYI and Tamás TÓTH

Often religious buildings fall into a state of neglect, here a Roman Catholic Church suffered from a combination of problems: being part of a none too sympathetic urban composition and neglect due to dissolution during the communist era. The architects responsible for the restoration started by making a full digital survey of the building from which analysis of required works could be implemented. Improvements to the building's fabric, quality of lighting and its place in the urban context have been vastly improved upon.

\section{DUMBOVARI, JanOS: REPAIREDFINALE}

Citation: Metszet, Vol 11, No 5 (2020), pp 58-63, DOI: 10.33268/Met.2020.5.7

\section{HARD ROCK HOTEL, BUDAPEST, HUNGARY Architects: László SZÁSZ and Erzsébet HAJNÁDY}

Following the established business model of the Hard Rock company design concepts are handled by their local franchise partner. Here the decision was made to respect the existing building's elevations, whilst adding a three storey high golden crown that responds to the location, Nagymezó Utca's, Broadway like ambitions. To lift a corner site architecturally with a bold, traditionally, out of context statement. This approach completes the problem of a poorly massed streetscape whilst adding a taste of Rock ' $n$ ' Roll rebellion. 